\title{
Survival of the funded: Econometric analysis of startup longevity and success
}

\author{
Daniel Keogh ${ }^{1}$, Daniel K.N. Johnson ${ }^{2}$
}

\begin{abstract}
PURPOSE: The existing literature on the success of startup enterprises is thorough in investigating individual factors, but relatively weak in testing those factors in combination. This research tests for interactive effects, i.e., complementarities, between those factors. METHODOLOGY: We use a Cox proportional hazard model to estimate longevity in startups, supplementing it with maximum likelihood estimation of two metrics of success (employment and revenue). In each model, we explicitly test for interactions between terms, thus advancing the literature. FINDINGS: Panel data analysis shows that financing strategy matters to startup success, especially when combined with specific human and social capital attributes of the founders. For example, angel investors and venture capital investors benefit differently from founders with industry experience; founders with higher educational achievement generate more revenue than their peers specifically when their startups collaborate in university partnerships. IMPLICATIONS FOR THEORY AND PRACTICE: The paper suggests specific ways in which entrepreneurs should think about financing options that are complementary with their founder attributes. Further, it suggests that the literature must be very thoughtful, not only about the indicators of success but about advice to policymakers, financiers and entrepreneurs because of the nuanced nonlinearities and interactions we demonstrate. ORIGINALITY AND VALUE: We contribute to the literature on startup financing with a large dataset, careful modelling of interactive complementarities of between inputs, correction of the potential sample selection bias in previous studies, and a suite of modelled outcomes (survival, employment, and revenue) which allow for nuanced results.
\end{abstract}

Keywords: startup, business survival, revenues, venture financing, human capital, competitive advantage, new ventures, firm performance

1 Daniel Keogh, Data Scientist, Quantum Metric, 10807 New Allegiance Dr, Ste 155, Colorado Springs, CO 80921, USA, e-mail: dansekeogh@gmail.com

2 Daniel K.N. Johnson, Ph.D., Professor of Economics, Colorado College, Department of Economics and Business, 14 E Cache la Poudre Street, Colorado Springs, CO 80903, USA, e-mail: djohnson@coloradocollege.edu (ORCID ID https:// orcid.org/0000-0002-5142-0940). 


\section{INTRODUCTION}

There is a long literature about why new businesses fail. Yet that literature appears inadequate in light of the fact that the failure rate of new businesses is 90\% (Carrigan, 2020) in the United States, where those same new businesses account for as much as $50 \%$ of new job creation year-to-year across a host of industries (Fairlie et al., 2016). That combination of facts has led to the development of new capitalization strategies, including venture capitalists (VCs) and angel investors, exclusively for high-risk investment scenarios. Our research here improves existing models of startup survival and success, adding to the literature in several critical ways. We use multiple alternative models of success, interaction terms to permit nonlinear outcome response functions, and nuanced estimation strategies, which all contribute to a more detailed understanding of startup success via financing choices.

Many investors in startups value analytical evidence on the quantitative traits of a firm which pre-determine success, but other investors look almost exclusively at the qualitative traits of the startup and the character traits of successful founders which predict survival (Kleinert et al., 2020; Wang et al., 2019). Still, others take a special interest in specific industries, with investment decisions informed largely by their familiarity and expertise in a certain field. These investment philosophies have likened startup investing to horse racing: one can bet on the jockey (the entrepreneur), the horse (the business), or the race (the industry/market), as pointed out by Kaplan et al. (2009). In practice, successful investors are informed by all three philosophies in tandem. Given that venture capital investment in startups exceeded $\$ 300$ billion in 2020 despite the pandemic (Teare, 2021), it is expensive if we place the wrong bets. While the literature has thoughtfully explored the separate contributors of success, it has been very limited in measuring the interactions between those same factors.

This paper will model and test potential complementarities between financing strategies and the personal attributes of the entrepreneurs, using survival rates as a measure of success. In other words, it might be critical to recognize that some financing strategies work best in conjunction with other inputs/factors and less well on their own. We recognize that survival (i.e., "continued existence") masks a diversity of outcomes, so we also model revenue growth and employment levels to round out the picture. Finally, this is the first paper, of which we are aware, to correct for potential sample selection bias in performing startup-survival modeling. The resulting analysis is a test of the hypothesis that it is a combination of factors that matter for startup success, that no one financing strategy is superior on its own, but rather it is nuance and context (the presence of other factors) that are critical. 


\section{LITERATURE REVIEW}

As young firms, startups lack long time-trends of metrics used to evaluate older businesses; the question of how to identify and measure startup success is an argument in the economic literature (Laitinen, 2019; Baluku et al., 2016). Research has diverged into predominantly two directions: a) through the presence of successful financing under the hypothesis that investment by a competitive source is a strong signal of success (e.g., Wang et al., 2019), and b) through metrics standard in evaluating older ventures. That latter path is exemplified by studies using firm survival (Hipp and Binz, 2020), sales growth (Bednar et al., 2018), turnover (Kim, 2020), or return on equity (Laitinen, 2019). Since objective success and financing outcomes are inextricably linked, investor financing may be determined, which then creates further success either objectively or via subsequent rounds of subjective investor decisions (Kleinert et al., 2021).

Typically, Cox proportional hazard functions are used to measure new-venture survival, although with varying levels of success (Cader \& Leatherman, 2011; Delmar \& Shane, 2006). Other survival-time regressions are also common depending on data availability (Bosma et al., 2004), and for non-binary indicators such as revenues or employment, more conventional maximum likelihood estimation of probits, logits, and tobits are traditional (Bosma et al., 2004; Delmar \& Shane, 2006). However, there is inherent bias in these non-binary regressions as data panels are invariably unbalanced with missing values from failed firms; researchers have coped with this bias in a variety of ways (e.g., Boehmke et al., 2006; Cader \& Leatherman, 2011).

The proposition that a firm's financing technique can explain success is a popular thought (Baum \& Silverman, 2004; Huyghebaert et al., 2007; Ahmed \& Cozzarin, 2009; Yankov et al., 2014). However, if that decision is itself endogenous, a function of characteristics of the market or founder, then the story and model must become more complex. Several studies model the first endogenous stage, investment criteria, via the effects of the entrepreneur, industry, and the firm's strategy on venture success (Kleinert et al., 2020; Wang et al., 2019; Van Gelderen, 2004). Previous literature has found strong links between the entrepreneur and the firm's financing, so this begs questions as to when both are accounted for, if either of these have effects on new venture success (Sanyal \& Mann, 2010; Baum \& Silverman, 2004).

In a two-stage model, financial intermediaries not only select which firms get financing but influence survival and other success outcomes. Baum and Silverman (2004) describe how venture capital, for example, identifies potential and offers validation as well as the coaching and resources that a startup needs to survive: not just funding but portfolio company alliances, 
or advisors. However, the effects were entangled, since more funding correlated with founder characteristics, more alliances, more intellectual capital and more human or network capital, making it impossible to determine the true "causes" of success (Baum \& Silverman, 2004) This opens debate about the differences between financial, human capital and social capital, and how each affect new-venture success (Bosma et al., 2004; Yankov et al., 2014; Larson, 1992). In a sense, founder traits come first, and determine the type and amount of funding that a startup may receive. In their research, Sanyal and Mann (2010) analyze how an entrepreneur's assets, communication of relevant information, and personal characteristics predict what type of financing they pursue or attain. They find that more educated entrepreneurs are more likely to pursue debt-financing while serial entrepreneurs are just as likely to self-fund, pursue external debt, or external equity due to mitigated information opacity.

Given the choice of funding, Bosma et al. (2004) quantified the effects of financing strategy, controlling for talent. They conclude that human capital (such as education or startup experience) and social capital (such as a geographic location or ties to industry professionals) play a decisive role in predicting survival, profit, and employment. Cooper et al. (1994) conclude that general human capital such as education level and demographics play a stronger role in success than managerial know-how such as past entrepreneurial experience and advisors do. However, there is active debate on their relative effects (Baum \& Silverman, 2004; Bosma et al., 2004; Yankov et al., 2014). Delmar and Shane (2006) added the additional insight that the distinction between general and managerial-specific human capital varies with the age of the startup. In essence, there is a strong correlation or complementarity between factors predictive of success, with little clarity on which comes first (Bapna, 2019).

Founder identity attributes were found to be statistically significant by Banir (2014) in his paper evaluating determinants of gender differentials in the entrepreneurial space. Models that closely resemble this study include such controls whenever the entrepreneur is evaluated (Bosma et al., 2004; Sandberg \& Hofer, 1987). Clearly, factors beyond financing and founder attributes must also be considered. For example, Conti et al. (2013) found that patents, especially in certain industries, are significantly and largely predictive of new venture performance. Other studies use intellectual property variables to control for novelty of a product and innovative capacity of the firm (Baum \& Silverman, 2004; Sanyal \& Mann, 2010). Not controlling for industry or sector may skew the results (Yankov et al., 2014). With many investors looking exclusively at specific industries, it is important to account for the fact that this selection bias in the investment process may not be 
explained by the venture financing variables (Sanyal \& Mann, 2010; Cooper et al., 1994). Hence, we will be careful to include panel effects for each economic sector in the analysis that follows.

Building on this literature then, this paper proposes an empirical test of the hypothesis that financing strategy effectiveness is significantly dependent upon (and complementary with) founder characteristics. We hypothesize a structure for that exploration in the subsequent section, a model that reflects the complexity while attaining clear results.

\section{METHODOLOGY}

Suppose that survival is modeled as a binary outcome using the Cox proportional hazard function so that

$$
\begin{aligned}
& \text { Survival }(t)=\alpha_{s}(t) \exp \left(\sum \beta_{s, i} \text { financing }_{i}+\sum \gamma_{s, i} \text { collaboration }_{i}\right. \\
&+\sum \delta_{s, i} \text { intellectual property }_{i}+\sum \theta_{s, i} \text { human or social capital }_{i} \\
&+\sum \mu_{s, i} \text { founder demographics }_{i}+\sum \sigma_{s, i} \text { industry }_{i} \\
&\left.+\sum \tau_{s, i} \text { interactions }_{i}\right)+\varepsilon_{s}
\end{aligned}
$$

where coefficients are estimated for survival $(s)$ on each input's separate subtypes (i), which might affect survival probabilities independently. Specifically, financing is divided into six categories: angels, equity companies, venture capital, debt, government funding, and Friends/Family/Fools (FFF) sourcing. Collaboration, or competitive advantage, is recorded as a series of four binary indicators for the presence/absence of university partnerships, company partnerships, existing patent protection, and government lab collaboration. Intellectual property (IP) is listed as three count variables, the number of copyrights, trademarks, and patents owned. Human or social capital is recorded as years of education of the founder, previous founder work experience, and industry experience. Founder demographics are listed as binary variables to indicate the founder's identity as Hispanic, Native American, Asian, Black, and/or White, along with the age of the founder. We include fourteen industry indicator variables to accommodate for sectoral differences and five interaction terms to test for potential complementarities between human/social capital and collaborative or financing strategies. Naturally, there is also an error term included.

Using the results of that estimation, we propose two other dependent variables-revenues and employment-each also used to measure new- 
venture success (Hipp \& Binz, 2020; Bednar et al., 2018; Kim, 2020; Groenewegen \& de Langen, 2012; and others). Those additional dependent variables are modeled as conditional on survival to avoid sample selection bias by using only the surviving firms, but otherwise include the same explanatory variables. The model is therefore as follows, for revenue (with coefficients subscripted $r$ ) and for employment (with coefficients subscripted $e$ ):

$$
\begin{aligned}
\text { Revenue } \left._{(}\right)= & \alpha_{r}(t) \exp \left(\sum \rho_{r, i} \text { survival }+\sum \beta_{r, i} \text { financing }_{i}+\sum \gamma_{r, i} \text { collaboration }_{i}\right. \\
& +\sum \delta_{r, i} \text { intellectual propert } y_{i}+\sum \theta_{r, i} \text { human or social capital }{ }_{i} \\
& +\sum \mu_{r, i} \text { founder demographics }{ }_{i}+\sum \sigma_{r, i} \text { industry }_{i} \\
& \left.+\sum \tau_{r, i} \text { interactions }_{i}\right)+\varepsilon_{r}
\end{aligned}
$$

Employment $(t)$

$$
\begin{aligned}
& =\alpha_{e}(t) \exp \left(\sum \rho_{e, i} \text { survival }+\sum \beta_{e, i} \text { financing }_{i}\right. \\
& +\sum \gamma_{e, i} \text { collaboration }_{i}+\sum \delta_{e, i} \text { intellectual propert }_{i} \\
& +\sum \theta_{e, i} \text { human or social capital } i+\sum \mu_{e, i} \text { founder demographics } \text { foun }_{i} \\
& \left.+\sum \sigma_{e, i} \text { industr }_{i}+\sum \tau_{e, i} \text { interactions }_{i}\right)+\varepsilon_{e}
\end{aligned}
$$

where survival is a set of three variables in a two-stage least squares correction for sample selection; those variables are a constant, the explicit instrument for survival and lagged revenues to correct for trend effects. Since these variables are continuous but non-negative, we use a limited information maximum likelihood approach with instrumental variables to eliminate concerns about non-normality and heteroskedasticity.

One of the critical and creative elements of this paper's model is a focus on the interaction vectors listed last in the models above, to test potential complementarities between inputs: the product of human capital with competitive advantage terms, and the interaction of human capital with venture financing. Our goal is to discern whether particular types or depths of human capital empower or erode the impact of other critical factors. To our knowledge, this paper is the first to test explicitly and empirically for the presence of those complementarities. In mathematical terms, our hypothesis is that the values of $\tau$ (coefficients on the interaction terms) are not zero, all other things are held equal.

Our data come from a noted primary source of startup data, the Kauffman Firm Survey (KFS), which was conducted annually by Mathematica Policy 
Research (Kauffman Foundation, 2021). The sample observed 4,298 firms over the 2005-2012 period, registering questions on the founders and the firms spanning demographics, financials, strategy, and organization. Unfortunately, it would be impractical to collect those proprietary data ourselves, so we rely on the reputation of the KFS for data integrity and anonymization.

Survival is defined until a firm reported that it was out of business or failed to return the survey. If it reported having merged or been acquired, or if it missed a year of reporting before reappearing, it was removed from our sample entirely. Obviously, this researcher choice leads to potential bias, for example, if a firm failed to report in the last sample year but is still in business. It also leads to potential bias against firms that are successful, so successful that they were acquired or merged with other firms. However, from our perspective we could not discern the reasons for those events so we chose to avoid potentially false interpretations. Therefore, of our 3,768 sample firms, a little more than one-quarter fail in the first year, while more than one-third survive through all eight years.

Employment and revenues were more easily defined as self-reported by surveyed firms. In the first year of the sample, median employment is 1.5 employees, while in the last year surviving firms had a median employment of 4.1 employees. Median revenue level in the first sample year is 3.73 on a categorical survey scale where level 3 is $\$ 1,001-\$ 3,000$ and level 4 is $\$ 3,001-\$ 5,000$. Surviving firms in the final year showed a median revenue level of 7.25 , consistent with $\$ 25,001-\$ 100,000$.

The specific types of financing of interest are Friends, Family, and Fools (FFF) money, Venture Capital (VC), Angel financing, Government Investment, or Debt. The identification of these types is meant to capture the effects on performance that are implicit with different kinds of financing. By including these variables, one can explore what the combination of founder capital and types of financing have on the success of the firm.

Venture financing in our analysis is defined as a binary variable, because although there were survey questions about equity percentage, most respondents did not complete those questions. Debt financing was more thoroughly reported by respondents, but funding by Friends, Family, and Fools (FFF) was once again binary due to reporting limitations. In 2004, for example, there are 69 firms that received angel investment ( 1.8\%), 44 with company equity ( 1.1\%), 18 ( 0.5\%) with government investment, 20 ( 0.5\%) with VC investment, 129 ( 3.4\%) with FFF investment, and about 2,011 ( 53\%) that pursued debt financing. We treat the excluded category as implicitly selffunded, and of course, partial funding by one of the listed sources implies self-funding of the remainder as well. These listed percentages decrease over time but generally remain at a constant share of surviving firms. 
The competitive advantages of the firm are broken down into partnerships that the firm has with different entities (university, government lab or research center, private company, or a patent advantage). On one hand, these advantages are often seen as the result of receiving certain types of funding, such as VCs linking up portfolio companies or facilitating a connection to government (Baum \& Silverman, 2004). On another, prefunding competitive advantages have been found to be one of the strongest predictors in receiving venture financing (Conti et al., 2013). All-in-all, these variables are key in measuring firm networks, as they are the most tangible input the data set has for relationships that may cause success.

Survey questions related to specific types of competitive advantages were only asked starting in 2007 , as opposed to an aggregate question about the presence or absence of competitive advantages which was asked in 20042006. We assumed no change in the nature of those competitive advantages, and backfilled for years prior to 2007. Thus, in 2004-2007 there are 95 firms ( $2.5 \%$ of the sample) with university partnership competitive advantages, 337 firms ( $8.9 \%$ of the sample) with company partnership competitive advantages, 115 firms ( $3 \%$ of the sample) with patent competitive advantages, and 40 firms ( $1.1 \%$ of the sample) with a government lab competitive advantage. These absolute numbers typically fall over time, but rise as a percentage of firms that have survived. It is also worth controlling for the specific types of intellectual property (IP) that each startup controls: trademarks, copyrights, and patents. While our median sample firm held no IP of any sort, some prolific and heavily legally protected firms are worth respecting with this separation of IP types.

In the case of multiple founders, we included only the attributes of the primary founder. Education had to follow the initial survey style, which categorized the highest level of education attained on a scale of 1 (less than secondary school) through 10 (doctoral degree), and the median education value is 6.26 (between an associate's and bachelor's degree). Age was similarly constrained to a scale from 1 (ages 18-24 years) through 7 (over 75 years), with a median of 3.55 (where level 3 is ages 35-44 and level 4 is 4554). Approximately one in 6 founders had relevant founder experience, and the average founder had 12.7 years of other professional experience.

The model will also contain founder characteristics, to control for nonhuman capital-based factors that a founder may bring to a startup that still may influence its performance, such as age and race. The vast majority of founders identified as white (82\%). Naturally, we want to include control variables to isolate effects properly. The first group of control variables is industry specific controls, accounting for NAICS codes, as well as if the founder identifies the firm as high-tech. In our sample, 511 firms (13\%) are 
self-defined as "high-tech" at the beginning of the sample, a percentage that increases with attrition. The industries most strongly represented were manufacturing (18\%) and professional services (25\%).

\section{RESULTS}

Some of the Cox proportional hazard survival regression results are (happily) unsurprising. Robustness tests that included alternative control variables for size (whether measured by total assets, total liabilities, or total debt) or region showed no effect on the remaining coefficients, so they were omitted to avoid potential collinearity with the central variables of interest. Turning to the variables central to this study, we report their estimated impact on survival in Table 1.

Table 1. Survival regression results

\begin{tabular}{llll}
\hline Variable & Hazard Ratio & Std Error & Z-Statistic \\
\hline Financing ( $\boldsymbol{\beta})$ & & & \\
\hline Angels & $0.2885^{* *}$ & 0.1739 & -2.06 \\
Equity companies & 0.4845 & 0.2525 & -1.39 \\
Venture capital & 1.0343 & 0.4776 & 0.07 \\
Debt & $0.1381^{* * *}$ & 0.0093 & -29.38 \\
Government & $3.6150^{* * *}$ & 1.4939 & 3.11 \\
FFF & $0.5581^{* *}$ & 0.1623 & -2.01 \\
\hline Competitive advantages and collaboration $(\boldsymbol{\gamma})$ & & \\
\hline University & $0.6829^{* * *}$ & 0.1583 & -1.65 \\
Company & $0.1751^{* * *}$ & 0.0283 & -10.76 \\
Patent (yes/no) & 0.5071 & 0.1332 & -2.59 \\
Government Lab & 0.7629 & 0.1830 & -1.13 \\
Intellectual property ( $\boldsymbol{\delta})$ & & & \\
Copyrights (count) & $0.9330^{* *}$ & 0.0283 & -2.29 \\
Trademarks (count) & $0.6316^{* * *}$ & 0.0765 & -3.8 \\
Patents (count) & $0.9998^{* * *}$ & 0.0000 & -4.2 \\
\hline Human and social capital of founder $(\boldsymbol{\theta})$ & & \\
\hline Education level & $0.9774^{* *}$ & 0.0091 & -2.46 \\
Previous founder experience & 1.0842 & 0.0550 & 1.59 \\
Industry experience & $0.9903^{* * *}$ & 0.0020 & -4.82 \\
\hline
\end{tabular}




\begin{tabular}{|c|c|c|c|}
\hline Variable & Hazard Ratio & Std Error & Z-Statistic \\
\hline \multicolumn{4}{|c|}{ Founder demographics $(\mu)$} \\
\hline Hispanic & $1.2867 * * *$ & 0.1022 & 3.17 \\
\hline Native American & 0.9757 & 0.0987 & -0.24 \\
\hline Asian & 0.8589 & 0.1068 & -1.22 \\
\hline Black & 1.1175 & 0.1065 & 1.17 \\
\hline White & 0.8641 & 0.0698 & -1.81 \\
\hline Age & $0.9601 * * *$ & 0.0171 & -2.28 \\
\hline \multicolumn{4}{|c|}{ Industry $(\sigma)$} \\
\hline Mining & 1.2445 & 0.7350 & 0.37 \\
\hline Construction & 0.6574 & 0.3340 & -0.83 \\
\hline Utilities & 1.1000 & 0.0771 & 1.36 \\
\hline Manufacturing & 1.0302 & 0.0605 & 0.51 \\
\hline Transportation and Warehousing & 1.0937 & 0.1260 & 0.78 \\
\hline Information & 0.8324 & 0.0938 & -1.63 \\
\hline Financial Services & 1.0458 & 0.1014 & 0.46 \\
\hline Real Estate & $0.8250^{*}$ & 0.0962 & -1.65 \\
\hline Professional Services & $0.8898 * *$ & 0.0519 & -2.00 \\
\hline Management & $2.0140 * * *$ & 0.4724 & 2.98 \\
\hline Waste management & 0.9563 & 0.0727 & -0.59 \\
\hline Education & 0.8693 & 0.2271 & -0.54 \\
\hline Recreation & 0.9518 & 0.1277 & -0.37 \\
\hline Food & $1.3191 * *$ & 0.1743 & 2.1 \\
\hline High tech & 1.0171 & 0.0632 & 0.27 \\
\hline
\end{tabular}

Selected interactions of human capital with competitive advantage $(\tau)$

\begin{tabular}{llll}
\hline $\begin{array}{l}\text { Founder education } x \text { university } \\
\text { collaborator }\end{array}$ & $0.8944^{* * *}$ & 0.0256 & -3.9 \\
$\begin{array}{l}\text { Relevant industry experience } x \\
\text { company collaborator }\end{array}$ & $0.1516^{* * *}$ & 0.0537 & -5.33 \\
$\begin{array}{l}\text { Previous founder experience } x \\
\text { company collaborator }\end{array}$ & $0.9047^{* * *}$ & 0.0125 & -7.25 \\
\hline
\end{tabular}

Selected interactions of human capital with financing style $(\tau)$

\begin{tabular}{llll}
\hline $\begin{array}{l}\text { Relevant industry experience } x \\
\text { venture capital }\end{array}$ & 0.5478 & 0.5419 & -0.61 \\
$\begin{array}{l}\text { Relevant industry experience x equity } \\
\text { company }\end{array}$ & 0.4074 & 0.4322 & -0.85 \\
\hline
\end{tabular}

Note: ${ }^{*}$ indicates significance the $10 \%$ level; ${ }^{* *}$ indicates significance at the $5 \%$ level; ${ }^{* * *}$ indicates significance at the $1 \%$ level. 
Most notably among financing variables $(\beta)$, firms financed by a government source are much more likely to fail, at a hazard rate 3.6 times the failure rate of other sample firms. At the other extreme, FFF equity appears to improve survival, cutting hazard rates almost in half. Safest of all are angel investments and debt financing, which reduce the risk of failure by 71 and 86 percent respectively, both remarkable risk reductions not only statistically but financially. Other financing choices show no statistically significant effects.

Competitive advantages $(\gamma)$ reduce the risk of failure demonstrably as well, especially for university partnerships (by 32 percent) and commercial partnerships (by 82 percent). Lab partnerships are associated with a hazard reduction but show no statistical significance. The presence of patents alone does not appear significant, but once the quantity of intellectual property $(\delta)$ is factored into the equation, more copyrights, more patents and especially more trademarks all serve to significantly reduce the risk of failure with each additional piece of IP.

Founder education and previous experience $(\theta)$ in the industry both help to reduce failure risk at statistically significant levels, but previous startup leadership by the founder has no statistical relevance.

Interestingly, among founder identities $(\mu)$, Hispanic founders have a significantly higher hazard rate than others, ceteris paribus, a pattern which bears further investigation by other scholars. Age serves to reduce risk, with older founders failing less often at the rate of roughly 4 percent per 10-year age tranche.

We found statistically significant industry effects $(\sigma)$ in our sample, with real estate and professional services outperforming other sectors while management and food companies failed at a higher rate than their peers.

Most importantly, as evidence on our primary hypothesis (the significance of $\tau$ coefficients), there is strong and robust evidence that founder human capital interacts powerfully with a range of competitive advantage variables. In other words, more educated founders obtain even more benefit from a university collaboration, and more experienced founders (or repeat entrepreneurial founders) obtain exponential benefits from a commercial collaboration. Interestingly though, the same interaction does not hold true for financing strategy; founder human capital does not seem to complement financing strategy to broker survival success.

Revenues and employment are estimated with instrumentalvariable, limited-information, maximum likelihood regressions. Survival is instrumented using survival predictions from the previous regression. To account for the effects of trend, lagged values are included as independent variables. Unfortunately, remember that revenues were reported on the survey on a range scale. Table 2 presents results for revenue on the left and 
employment on the right. Notice first of all that the corrections for survival bias and lagged values $(\rho)$ are all highly statistically significant.

Table 2. Revenues and employment by LIML IV Regression

\begin{tabular}{|c|c|c|c|c|c|c|}
\hline \multirow[b]{2}{*}{ Variable } & \multicolumn{3}{|c|}{ Revenues } & \multicolumn{3}{|c|}{ Employment } \\
\hline & Coeff & Std Error & Z-Stat & Coeff & Std Error & Z-Stat \\
\hline \multicolumn{7}{|c|}{ 2SLS Controls $(\rho)$} \\
\hline Constant & $-0.599^{* * *}$ & 0.0771 & -7.77 & $-0.433^{* * *}$ & 0.1218 & -3.55 \\
\hline Survival instr & $3.272^{* * *}$ & 0.3270 & 10.01 & $1.193^{* * *}$ & 0.4297 & 2.78 \\
\hline Lagged rev & $0.528^{* * *}$ & 0.0193 & 27.41 & $0.873^{* * *}$ & 0.0221 & 39.45 \\
\hline \multicolumn{7}{|c|}{ Financing $(\beta)$} \\
\hline Angels & $0.550^{* * *}$ & 0.1840 & 2.99 & 0.314 & 0.3284 & 0.96 \\
\hline Equity comp & 0.073 & 0.2435 & 0.30 & 0.459 & 0.3040 & 1.51 \\
\hline Venture capital & -0.068 & 0.3760 & -0.18 & -0.816 & 0.5249 & -1.55 \\
\hline Debt & -0.165 & 0.1411 & -1.17 & -0.074 & 0.2315 & -0.32 \\
\hline Government & -0.249 & 0.4721 & -0.53 & 1.807 & 1.1797 & 1.53 \\
\hline FFF & -0.123 & 0.1614 & -0.76 & 0.003 & 0.2418 & 0.01 \\
\hline \multicolumn{7}{|c|}{ Competitive advantages and collaboration $(\gamma)$} \\
\hline University & $-0.444^{* * *}$ & 0.1160 & -3.83 & 0.138 & 0.1800 & 0.77 \\
\hline Company & 0.078 & 0.0824 & 0.94 & -0.112 & 0.1397 & -0.80 \\
\hline Patent (yes/no) & 0.096 & 0.1405 & 0.68 & 0.219 & 0.2797 & 0.79 \\
\hline Gov Lab & -0.052 & 0.0988 & -0.52 & -0.010 & 0.1998 & -0.05 \\
\hline \multicolumn{7}{|c|}{ Intellectual property $(\delta)$} \\
\hline Copyrights (\#) & 0.001 & 0.0021 & 0.47 & -0.002 & 0.0029 & -0.78 \\
\hline Trademarks (\#) & 0.001 & 0.0001 & 1.64 & $0.001^{*}$ & 0.0001 & 1.71 \\
\hline Patents (\#) & 0.001 & 0.0001 & -0.49 & 0.001 & 0.0001 & -0.75 \\
\hline \multicolumn{7}{|c|}{ Human and social capital of founder $(\theta)$} \\
\hline Education level & $0.015^{* *}$ & 0.0059 & 2.47 & 0.003 & 0.0080 & 0.33 \\
\hline Founder exper & $0.064^{*}$ & 0.0331 & 1.92 & 0.068 & 0.0515 & 1.33 \\
\hline Industry exper & $0.003^{* *}$ & 0.0012 & 2.08 & $0.003^{*}$ & 0.0016 & 1.92 \\
\hline \multicolumn{7}{|c|}{ Founder demographics $(\mu)$} \\
\hline Hispanic & -0.058 & 0.0556 & -1.04 & 0.102 & 0.0821 & 1.24 \\
\hline Native Am & $-0.1884^{* *}$ & 0.0767 & -2.46 & -0.074 & 0.0849 & -0.87 \\
\hline Asian & $-0.1383^{*}$ & 0.0820 & -1.69 & 0.024 & 0.1313 & 0.19 \\
\hline Black & $-0.1033^{*}$ & 0.0604 & -1.71 & 0.158 & 0.1021 & 1.55 \\
\hline White & 0.0226 & 0.0515 & 0.44 & 0.037 & 0.0872 & 0.43 \\
\hline Age & $-0.054^{* * *}$ & 0.0123 & -4.37 & $-0.051^{* * *}$ & 0.0170 & -2.98 \\
\hline
\end{tabular}




\begin{tabular}{lcccccc}
\hline \multicolumn{7}{c}{ Industry } \\
\hline Mining & -0.058 & 0.3437 & -0.17 & -0.058 & 0.1878 & -0.31 \\
Construction & -0.609 & 0.4339 & -1.40 & $-0.418^{* *}$ & 0.1962 & -2.13 \\
Utilities & 0.018 & 0.0496 & 0.36 & 0.077 & 0.0697 & 1.11 \\
Manufacturing & $0.179^{* * *}$ & 0.0372 & 4.81 & 0.057 & 0.0515 & 1.1 \\
Transport and Warehousing & 0.109 & 0.0771 & 1.42 & 0.167 & 0.1068 & 1.56 \\
Information & -0.049 & 0.0633 & -0.78 & -0.066 & 0.0797 & -0.83 \\
Finan Services & -0.088 & 0.0692 & -1.27 & -0.035 & 0.0686 & -0.51 \\
Real Estate & $-0.215^{* * *}$ & 0.0737 & -2.92 & -0.034 & 0.0706 & -0.48 \\
Prof Services & 0.051 & 0.0352 & 1.44 & -0.061 & 0.0426 & -1.43 \\
Management & 0.157 & 0.2387 & 0.66 & 0.113 & 0.5029 & 0.22 \\
Waste mgmt & -0.075 & 0.0486 & -1.55 & -0.078 & 0.0581 & -1.34 \\
Education & -0.139 & 0.1540 & -0.90 & -0.181 & 0.1502 & -1.21 \\
Recreation & -0.039 & 0.0766 & -0.51 & -0.081 & 0.0756 & -1.07 \\
Food & -0.016 & 0.0977 & -0.17 & $-0.494^{* *}$ & 0.1967 & -2.51 \\
High tech & $0.098^{* *}$ & 0.0458 & 2.13 & 0.112 & 0.0753 & 1.49 \\
\hline
\end{tabular}

\begin{tabular}{lcccccc}
\hline \multicolumn{7}{c}{ Selected interactions of human capital with competitive advantage } \\
\hline Founder educ x univ collaborator & $-0.053^{* * *}$ & 0.0145 & -3.63 & 0.018 & 0.0209 & 0.89 \\
Industry exper x comp collab & $0.118^{*}$ & 0.1157 & 1.02 & $0.337^{*}$ & 0.1955 & 1.72 \\
Founder exper x comp collab & 0.0037 & 0.0030 & 1.27 & 0.009 & 0.0042 & 0.21 \\
\hline \multicolumn{7}{c}{ Selected interactions of human capital with financing style } \\
\hline Industry exper x angel investing & $1.2132^{* * *}$ & 0.2775 & 4.37 & $1.616^{* * *}$ & 0.6413 & 2.52 \\
Industry exper x venture capital & $-1.399^{*}$ & 0.7909 & -1.77 & $-3.075^{* * *}$ & 1.2444 & -2.47 \\
Industry exper x equity company & 0.2391 & 0.3613 & 0.66 & $1.515^{* *}$ & 0.5509 & 2.75 \\
\hline
\end{tabular}

Note: ${ }^{*}$ indicates significance the $10 \%$ level; ${ }^{* *}$ indicates significance at the $5 \%$ level; $* * *$ indicates significance at the $1 \%$ level.

Among financing strategies $(\beta)$, receiving angel equity is a strongly significant predictor of higher revenues, conditional upon survival. No form of financing strategy was significantly correlated with employment success. Competitive advantages and collaborations $(\gamma)$ with universities resulted in lower revenues than other new firms, presumably because the emphasis might be more on scientific development and knowledge acquisition than on commercialization. No other form of collaboration or even form of intellectual property was notably correlated with either revenue or employment outcomes.

However, this is where founder attributes $(\theta$ and $\mu)$ start to shine. Founder education, previous startup experience and previous work in the industry all contribute meaningfully to increased revenues in the startup. Industry 
experience also has a small positive employment effect. Disappointingly, there is also a racial impact obvious here, with white founders outperforming other ethnicities with statistical significance. Age also shows up here, with younger founders on average leading new firms to higher revenues.

While there are also a few industry-specific effects $(\sigma)$, the most interesting part of the results table summarizes the importance of interaction terms $(\tau)$ as hypothesized between founder attributes and strategic collaborations. Founders with higher education levels are even more prone to earn lower revenues when collaborating with a university, while founders with more industry experience are more likely to earn higher revenues (and employ more workers) when collaborating with a commercial ally. This is completely consistent with the supposition that university partnerships might focus more on knowledge while business partnerships might focus more on commercialization and profit-generating strategies.

Finally, notice that angel investors get an additional boost from founders with relevant industry experience, both in terms of revenue and employment. That completely contrasts with the effects for venture capital firms, which see a decrease in revenues and employment from the same combination of founders with relevant industry experience. Equity companies look more like angel investors in this way, with positive employment outcomes but no significant revenue effects.

Robustness tests were performed exhaustively, to guard against endogeneity, unit roots, and mis-specification of functional form. All results signified correct specification. It should also be noted that for the model where adjusted R-squared or Wald tests apply, the model performs well in explaining variation; Wald scores are universally significant at the 99 percent level, and adjusted R-squared values exceed 0.68 .

\section{DISCUSSION}

Our results show that human and social capital variables and collaborative or financing strategy both predict firm success, not only alone, as shown by the literature, but when interacted with each other (a new result). Thus, this paper contributes to the discussion about how to identify and measure startup success, alongside Hipp and Binz (2020), Kim (2020), Laitinen (2019), and Baluku et al. (2016).

We find strong survival effects of specific financing strategies like government, angel, debt and FFF investing (consistent with Yankov et al., 2014), but further conclude that all were reinforced with the presence of founder experience in the industry or education level (connecting our results 
with Sanyal \& Mann, 2010). Our results could very well inform subsequent rounds of investor decisions (in the flavor of Kleinert et al., 2021).

For example, highly educated founders were more successful than their peers in generating startup revenue specifically when they used a collaborative strategy involving partnership with a university. This suggests a latent effect, the potential for university alumni to collaborate with their former faculty or institution in a way that non-alumni cannot (but this must be confirmed via future research that matches founders with specific collaborative institutions).

In contrast, industry experience was most effective when combined with angel investing (to achieve both revenues and employment), whereas industry experience combined with venture capital worked against success. This is a completely new finding in the literature, one which points to a potentially important difference between financing strategies as they interact with experienced founders. This result is consistent with the literature and perhaps explains differences between the outcomes of previous studies (e.g., Baum \& Silverman, 2004; Ahmed \& Cozzarin, 2009; Davila et al., 2001; Huyghebaert et al., 2007; Yankov, 2014; Kleinert et al., 2020). We could hypothesize about reasons for this new result, perhaps around issues of control and strategic direction of the startup (hearkening back to Cooper et al., 1994), but call for further research on this question.

Competitive advantages played a strong role in survival but were much weaker in predicting subsequent revenues or employment, arenas where social and human capital played a larger role, a result unique in the literature. Most importantly, our results show that correcting for survival bias is statistically important; a result largely omitted elsewhere in the literature (e.g., Cader \& Leatherman, 2011).

We must, of course, acknowledge remaining limitations encountered during the research process, limitations that might compromise our results. Survival itself is a constructed variable based on assumptions about respondents; revenues were coded in the original survey as level-indicator variables, so interpretations are not clean. Clearly, if our underlying data are not equally or randomly representative of different financing strategies (and there were relatively few equity-financed or venture capital-financed firms), our results may be unintentionally biased.

\section{CONCLUSION}

The findings of this study should inform the two major stakeholders in new ventures - entrepreneurs and investors. Both can conclude that new-firm survival is much less related to founder levels of experience than has been 
typically thought. Instead, when starting a business or building a team of cofounders, entrepreneurs should be just as cognizant of the network that they may collectively have and their ability to leverage the network into creating a successful company.

On the other hand, our findings do validate the concept of investing in the entrepreneur versus the idea, if the goal is not only survival but revenue creation and eventual profitability. Furthermore, particular founders seem to pair more effectively with particular financing strategies; angels might do well not to fund the same founders that venture capital funds do. Further research might do well to investigate the reasons for this result.

Government policy might reasonably be influenced by our results as well. Although a limited sample size, government equity was the strongest predictor of failure in all the regressions taken, registering a dramatically increased likelihood of failure. This raises questions about how (and if) we support new firms who receive government funding, and whether the goals of those public funds are appropriately used in predictably short-lived enterprises. Perhaps that is indeed the goal, to secure an objective and then let the business close, but if the goal is to create an entrepreneurial ecosystem, then this policy is, on average, dramatically less successful at picking and sustaining than are other forms of private funding. Implementing policies that help induce more collaboration and partnerships, whether through tax incentives, business classifications, or grants, could see a strong increase in overall new-venture survival, and firm success. Research might wisely inspect the reasons for this potentially very unproductive result.

In conclusion, although some variables do not explicitly agree with past literature, those disagreements are perhaps appropriate clarifications given our treatment of survival bias and interaction terms. Our major results do an excellent job of giving credence to past research and give substantial fodder for further research. For example, it might be important to know whether these results apply in other jurisdictions and nations, whether the interaction terms are significant for all founder demographics or solely for white men (as mostly represented in our sample), and whether funding in the postpandemic world will follow the same patterns or will shape new paths.

\section{Acknowledgments}

We thank the extremely helpful comments of two anonymous reviewers. 


\section{References}

Ahmed, S.T., \& Cozzarin, B.P. (2009). Start-up funding sources and biotechnology firm growth. Applied Economics Letters, 16(13), 13411345. https://doi.org/10.1080/13504850701367338

Baluku, M.M., Kikooma, J.F., \& Kibanja, G.M. (2016). Psychological capital and the startup capital-entrepreneurial success relationship. Journal of Small Business \& Entrepreneurship, 28(1), 27-54. https://doi.org/10.108 $0 / 08276331.2015 .1132512$

Bapna, S. (2019). Complementarity of signals in early-stage equity investment decisions: Evidence from a randomized field experiment. Management Science, 65(2), 933-952. https://doi.org/10.1287/mnsc.2017.2833

Barnir, A. (2014). Gender differentials in antecedents of habitual entrepreneurship: Impetus factors and human capital. Journal of Developmental Entrepreneurship, 19(1), 1450001. https://doi. org $/ 10.1142 /$ S1084946714500010

Baum, J.A.C., \& Silverman, B.S. (2004). Picking winners or building them? Alliance, intellectual, and human capital as selection criteria in venture financing and performance of biotechnology startups. Journal of Business Venturing, 19(3), 411-436. https://doi.org/10.1016/S08839026(03)00038-7

Bednar, R., Tariskova, N., \& Zagorsek, B. (2018). Startup revenue model failures. Montenegrin Journal of Economics, 14(4), 141-157. https://doi. org/10.14254/1800-5845/2018.14-4.1

Boehmke, F.J., Morey, D.S., \& Shannon, M. (2006). Selection bias and continuous-time duration models: Consequences and a proposed solution. American Journal of Political Science, 50(1), 192-207. https:// doi.org/10.1111/j.1540-5907.2006.00178.x

Bosma, N., Van Praag, M., Thurik, R., \& De Wit, G. (2004). The value of human and social capital investments for the business performance of startups. Small Business Economics, 23(3), 227-236. https://doi.org/10.1023/ B:SBEJ.0000032032.21192.72

Cader, H.A., \& Leatherman, J.C. (2011). Small business survival and sample selection bias. Small Business Economics, 37(2), 155-165. https://doi. org/10.1007/s11187-009-9240-4

Carrigan, M. (2020). 2019 small business failure rate: Startup statistics by industry. National Business Capital and Services Report, January. Retrieved from https://www.nationalbusinesscapital.com/2019-smallbusiness-failure-rate-startup-statistics-industry/

Conti, A., Thursby, M., \& Rothaermel, F.T. (2013). Show me the right stuff: Signals for high-tech startups. Journal of Economics \& Management Strategy, 22(2), 341-364. https://doi.org/10.1111/jems.12012

Cooper, A.C., Gimeno-Gascon, F.J., \& Woo, C.Y. (1994). Initial human and financial capital as predictors of new venture performance. Journal 
of Business Venturing, 9(5), 371-395. https://doi.org/10.1016/08839026(94)90013-2

Delmar, F., \& Shane, S. (2006). Does experience matter? The effect of founding team experience on the survival and sales of newly founded ventures. Strategic Organization, 4(3), 215-247. https://doi. org/10.1177\%2F1476127006066596

Dickson, P.H., \& Weaver, K.M. (1997). Environmental determinants and individual-level moderators of alliance use. Academy of Management Journal, 40(2), 404-425. https://doi.org/10.5465/256888

Fairlie, R.W., Morelix, A., Reedy, E.J., \& Russell, J. (2016). The Kauffman Index of Startup Activity: National Trends. Retrieved from https://papers.ssrn. com/sol3/papers.cfm?abstract_id=2883389

Groenewegen, G., \& de Langen, F. (2012). Critical success factors of the survival of start-ups with a radical innovation. Journal of Applied Economics and Business Research, 2(3), 155-171.

Foster, G., Davila, T., \& Gupta, M. \& (2001). The impact of rounds of venture capital funding on the growth strategy of startups. Retrieved from https://www.gsb.stanford.edu/gsb-box/route-download/317781

Hipp, A., \& Binz, C. (2020). Firm survival in complex value chains and global innovation systems: Evidence from solar photovoltaics. Research Policy, 49(1), 103876. https://doi.org/10.1016/j.respol.2019.103876

Kaplan, S.N., Sensoy, B.A. \& Stromberg, P. (2009). Should investors bet on the jockey or the horse? Evidence from the evolution of firms from early business plans to public companies. The Journal of Finance, 64(1), 75115. https://doi.org/10.1111/j.1540-6261.2008.01429.x

Kauffman Foundation. (2021). Kauffman Firm Survey (KFS) Series. Retrieved from https://www.kauffman.org/-entrepreneurship/research/dataresources/

Klabunde, A. (2016). How much should an investor trust the startup entrepreneur? A network model. Journal of Economic Interaction and Coordination, 11(2), 293-312. https://doi.org/10.1007/s11403-0150147-7

Kleinert S., Bafera J., Urbig D., \& Volkmann C.K. (2021). Access denied: How equity crowdfunding platforms use quality signals to select new ventures. Entrepreneurship Theory and Practice, May. https://doi. org/10.1177\%2F10422587211011945

Kleinert, S., Volkmann, C., \& Grünhagen, M. (2020). Third-party signals in equity crowdfunding: The role of prior financing. Small Business Economics, 54(1), 341-365.

Kim, J. D. (2020). Startup acquisitions as a hiring strategy: Worker choice and turnover. University of Pennsylvania Wharton School of Business Working Paper. Retrieved from https://papers.ssrn.com/sol3/-Papers. cfm?abstract_id=3252784 
Laitinen, E. (2019). Discounted Cash Flow (DCF) as a measure of startup financial success. Theoretical Economics Letters, 9(8), 97410. https://doi. org/10.4236/tel.2019.98185

Larson, A. (1992). Network dyads in entrepreneurial settings: A study of the governance of exchange relationships. Administrative Science Quarterly, 37, 76-104. https://doi.org/10.2307/2393534

MacMillan, Ian C., Siegel, R., \& Narasimha, P.N.S. (1985). Criteria used by venture capitalists to evaluate new venture proposals. Journal of Business Venturing, 1(1), 119-128. https://doi.org/10.1016/0883-9026(85)90011-4

Mann, C.L., \& Sanyal, P. (2010). The financial structure of startup firms: The role of assets, information, and entrepreneur characteristics. Working Paper 10-17, Federal Reserve Bank of Boston. Retrieved from http://hdl. handle.net/10419/5556

Mitter, C., \& Kraus, S. (2011). Entrepreneurial finance-issues and evidence, revisited. International Journal of Entrepreneurship and Innovation Management, 14(2-3), 132-150. https://doi.org/10.1504/ IJEIM.2011.041728

Otani, K. (1996). A human capital approach to entrepreneurial capacity. Economica, 63, 273-289. https://doi.org/10.2307/2554763

PriceWaterhouseCoopers \& National Venture Capital Association. (2016). MoneyTree Report. Historical Trend Data. Retrieved from https://www. pwc.com/us/en/industries/technology/moneytree/explorer.html\#/

Sandberg, W.R., \& Hofer, C.W. (1987). Improving new venture performance: The role of strategy, industry structure, and the entrepreneur. Journal of Business Venturing, 2(1), 5-28. https://doi.org/10.1016/08839026(87)90016-4

Sanyal, P., \& Mann, C.L. (2010). The financial structure of startup firms: The role of assets, information, and entrepreneur characteristics. Federal Reserve Bank of Boston Working Papers No. 10-17. Retrieved from https://www.econstor.eu/bitstream/10419/55565/1/642984506.pdf

Teare, G. (2021). Global VC Report 2020: Funding and Exits Blow Past 2019 Despite Pandemic Headwinds. Crunchbase News, January 13. Retrieved from https://news.crunchbase.com/news/global-2020-funding-and-exit/

Van Gelderen, M. (2004). A framework for conjecturing entrepreneurial opportunities: An application to individualization of demand in the undertaking business. Journal of Enterprising Culture, 12(4), 351-371. https://doi.org/10.1142/S021849580400018X

Yankov, B., Ruskov, R., \& Haralampiev, K. (2014). Models and tools for technology start-up companies success analysis. Economic Alternatives, 3, 15-24. https://www.unwe.bg/uploads/Alternatives/2_broi_3_2014.pdf

Wang, W., Mahmood, A., Sismeiro, C., \& Vulkan, N. (2019). The evolution of equity crowdfunding: Insights from co-investments of angels and the crowd. Research Policy, 48(8), 1-37. https://doi.org/10.1016/j. respol.2019.01.003 
Abstrakt
CEL: Istniejqca literatura na temat sukcesu przedsiębiorstw rozpoczynajacych działal-
ność jest dogłębna w badaniu poszczególnych czynników, ale stosunkowo nieliczna
w testowaniu tych czynników łącznie. Badanie to sprawdza efekty interaktywne, tj.
komplementarność między tymi czynnikami. METODYKA: Stosujemy model propor-
cjonalnego hazardu Coxa do oszacowania długowieczności w startupach, uzupeł-
niajqc go o oszacowanie maksymalnego prawdopodobieństwa dwóch miar sukcesu
(zatrudnienie i przychody). W każdym modelu wyraźnie testujemy interakcje między
terminami, tym samym rozwijajqc literaturę. WYNIKI: Analiza danych panelowych
pokazuje, że strategia finansowania ma znaczenie dla sukcesu startupu, szczególnie
w połqczeniu z określonymi atrybutami kapitału ludzkiego i społecznego założycieli.
Na przykład aniołowie biznesu i inwestorzy venture capital korzystajq z nich inaczej
niż założyciele z doświadczeniem w branży; założyciele z wyższym wykształceniem ge-
nerujq większe przychody niż ich rówieśnicy, zwłaszcza gdy ich startupy współpracujq
w ramach partnerstw uniwersyteckich. IMPLIKACJE DLA TEORII I PRAKTYKI: Artykuł
sugeruje konkretne sposoby, w jakie przedsiębiorcy powinni myśleć o opcjach finan-
sowania, które sq komplementarne z atrybutami ich założycieli. Co więcej, sugeruje
to, że literatura musi być bardzo przemyślana, nie tylko pod względem wskaźników
sukcesu, ale także porad dla decydentów, finansistów i przedsiębiorców ze względu
na zniuansowane nieliniowości i interakcje, które demonstrujemy. ORYGINALNość I WARTOŚć: Wnosimy wkład w literaturę dotyczqca finansowania startupów za pomoca dużego zestawu danych, starannego modelowania interaktywnej komplementarności między danymi wejściowymi, korekty potencjalnego błędu doboru próby w poprzednich badaniach oraz zestawu modelowanych wyników (przeżycie, zatrudnienie i przychody) które pozwalajq na zniuansowane wyniki.

Słowa kluczowe: startup, przetrwanie biznesu, przychody, finansowanie venture, kapitał ludzki, przewaga konkurencyjna, nowe przedsięwzięcia, wyniki firmy

\section{Biographical notes}

Dan Keogh is a Data Scientist based out of Boulder, Colorado. He received a bachelor's degree from Colorado College in Mathematical Economics in 2017. Currently, he builds anomaly detection and Natural Language Processing models for Quantum Metric, a Digital Experience Analytics company headquartered in Colorado. Prior to Quantum Metric, Dan was a Data Scientist for Seattle-area-based EagleView and in his own entrepreneurial pursuits, where he specialized in developing computer vision and geospatial machine learning models. His primary professional interests are developing machine learning models to process time-series, text, and image data, and the subsequent integration into modern software products. 
Daniel K.N. Johnson is a Professor of Economics at Colorado College, has founded several businesses and holds advisory roles in a range of other startups. He is the author of over sixty refereed journal articles, commissioned pieces, and book chapters. Specializing in the economics of innovation and technological change, he frequently advises and lectures internationally on public policy related to intellectual property rights. In addition to his primary research on spillovers from researchers to the Global South (or other potential follower groups), he enjoys writing projects that apply economic models to unusual questions including predicting Olympic medal counts (on which he did a TedTalk), explaining game show contestant behavior, exploring philanthropic behavior, measuring the impact of WalMart on home prices, improving the marginal impact of microfinance lending programs, and quantifying the effect of structural racism on COVID infection and mortality rates.

\section{Conflicts of interest}

The authors declare no conflict of interest.

\section{Citation (APA Style)}

Keogh, D.,\&Johnson, D.K.N.(2021). Survival of thefunded:Econometricanalysis of startup longevity and success. Journal of Entrepreneurship, Management, and Innovation, 17(4), 29-49. https://doi.org/10.7341/20211742 